\title{
Pelarangan Buku di Indonesia Era Orde Baru: Perspektif Panoptikon Michel Foucault
}

Muhammad Iqbal

Program Studi Sejarah Peradaban Islam, Fakultas Ushuluddin Adab dan Dakwah, IAIN Palangkaraya

\section{Abstrak}

Pelarangan buku adalah bentuk paradoks di negara demokrasi karena memperlihatkan kesewenang-wenangan dalam membatasi kebebasan berpikir, berpendapat, dan berekspresi. Padahal semua itu dijamin oleh prinsip-prinsip dasar demokrasi, bahkan secara tegas ditulis dalam Undang-Undang Dasar 1945. Melarang buku juga menjadi paradoks bagi kehidupan bermedia di Indonesia yang lebih dari satu dekade terakhir telah mengumandangkan dukungan terhadap kebebasan pers. Pelarangan buku, di sisi lain, mengindikasikan ambiguitas kebijakan penguasa. Alih-alih mengantisipasi polemik di masyarakat, lewat tindakan pelarangan buku, pemerintah memperlihatkan praktik-praktik primitif dalam mengontrol, mengarahkan, membatasi, bahkan memandulkan cara berpikir masyarakat. Pelarangan buku juga mencerminkan ketakutan penguasa dengan mengekang hak politik warga negaranya, tidak mengakui adanya keanekaragaman perspektif dan sudut pandang. Artikel ini ingin meneroka sejarah kebijakan pelarangan buku oleh rezim Orde Baru (Orba), guna mencatat perubahan bentuk dan orientasi yang melatari tindakan pelarangan buku sesuai konteks zamannya, serta apa dampaknya terhadap pendisiplinan masyarakat Indonesia.

\section{Kata Kunci: Pelarangan Buku, Orde Baru, Panoptikon}

\section{Pendahuluan}

Pelarangan buku di Indonesia dapat ditelusuri dari rekam jejak yang melintasi berbagai periodisasi zaman. Dirunut dari akar sejarahnya, pelarangan buku sebenarnya sudah jauh terjadi sejak zaman kerajaan-kerajaan di Nusantara. Kerajaankerajaan itu melarang berbagai bentuk perlawanan titah raja dengan dalih bahwa kekuasaan mutlak itu milik penguasa atau status raja sebagai representasi titisan dewa/Tuhan di dunia.

Dokumentasi sejarah pelarangan buku di Indonesia secara nyata mulai terlacak sejak masa kolonial. Bentuknya berupa pemenjaraan atau pengasingan seseorang karena hasil karyanya dianggap berlawanan dengan pandangan politik dan kebijakan pemerintah kolonial. Setelah merdeka, pelarangan buku tetap berlanjut, bahkan dengan ekskalasi yang terus meningkat, yakni dari masa Demokrasi Terpimpin di bawah kendali Soekarno dan mencapai puncaknya pada masa Orde Baru di bawah pimpinan Suharto. Setelah Orde Baru tumbang diganti era Reformasi, pelarangan buku dianggap tidak ada lagi.

Namun, kondisi bebas pelarangan buku tersebut ternyata tidak berlangsung lama. Era Reformasi yang mengusung agenda kebebasan berekspresi dan penegakan hak asasi manusia kembali melanggengkan praktik pelarangan buku. Fakta sejarah mencatat, motif utama pelarangan buku yang terjadi dari zaman ke zaman mengulang sebuah pola, yakni manifestasi otoritarianisme penguasa dan 
dominasi mayoritas yang ditopang legitimasi kekuasaan. Meskipun struktur kekuasaan berganti, budaya otoriter dari rezim yang berkuasa menjadi pendorong utama segala bentuk pemberangusan sikap kritis masyarakat. Ini dilakukan dengan cara memberi label "membahayakan keamanan", "mengganggu ketertiban umum", "tafsir yang keliru”, "ajaran sesat", dan sebagainya.

Kemudian, dalam rangka mencari pemahaman yang lebih baik mengenai sejarah pelarangan buku, uraian pada bab ini akan dibagi ke dalam tiga periode, yakni periode kolonial, demokrasi terpimpin, dan masa Orde Baru. Pembagian periode sejarah dalam penelitian ini didasarkan pada pertimbangan adanya kebijakan dan tindakan pelarangan buku oleh pemerintah yang berkuasa pada saat pelarangan itu berlangsung, dan bukan pada era kepemimpinan presiden siapa yang sedang menjabat.

Meskipun periode kolonial belum menjadi bagian dalam sejarah Indonesia merdeka, periode ini sengaja dimasukkan guna memberikan konteks atas pelarangan buku di Indonesia. Secara politis, paparan pada bagian ini pada dasarnya bertujuan untuk menunjukkan bahwa motif pelarangan buku pada masa Indonesia merdeka dan era kolonial tidaklah jauh berbeda. Semuanya demi kepen- tingan kekuasaan. Lalu, pengambilan periode demokrasi terpimpin didasarkan pada argumen bahwa pada era inilah demokrasi mengalami penyesatan, dan Soekarno sebagai pemimpin besar revolusi telah melakukan beberapa kesa- lahan. Pelarangan buku, karenanya, banyak terjadi pada masa ini. Berikutnya adalah pelarangan buku selama pemeritahan otoriter Orde Baru. Pada era kiwari, banyak buku dilarang karena alasan-alasan subsversif, menyebarkan paham marxisme-komunisme, atau karena penulisnya mempunyai hubungan dengan komunisme.

Periode kolonial menandai penjajahan berbagai sektor kehidupan. Berbagai peraturan yang ada semata-mata bertujuan mengendalikan orang-orang tanah jajahan agar tidak melawan apalagi memerdekakan dirinya. Saat itu, me- mang belum ada peraturan khusus berbentuk regulasi pelarangan buku. Namun, banyak penulis buku dipenjarakan atau diasingkan karena karya mereka dianggap berlawanan dengan pandangan politik dan kebijakan pemerintah kolonial.

Pelarangan brosur karya Soewardi Soerjaningrat bertajuk Seandainya Saya Warga Belanda (Als ik eens Nederlander was), misalnya, yang isinya mengecam peringatan 100 tahun lepasnya Belanda dari penjajahan Prancis pada 1913 yang dirayakan di Hindia Belanda, menjadi contoh konkret dalam hal ini. Dalam brosur itu, Seowardi menuturkan ironi masyarakat jajahan yang harus membiayai pesta kemerdekaan penjajah. Brosur itu dilarang 
beredar dan Soewardi Soerjaningrat diasingkan ke negeri Belanda. Salah satu koran besar pada masa itu, De Express tidak ketinggalan memuat isi brosur tersebut sebagai artikel. Dengan alasan "rust en orde" (keamanan dan ketertiban), penguasa kolonial menyita semua bentuk brosur pemikiran kritis Seowardi Soerjaningrat dan tokoh-tokoh pergerakan lainnya.

Meski reaksi bermunculan dari berbagai kalangan, tetapi pemerintah kolonial tetap pada keputusannya. Bahkan, pada tahun yang sama, Tjipto Mangoenkoesomo dan Douwes Dekker masing-masing dibuang ke Banda dan Kupang. Setelah melalui negosiasi, keduanya diizinkan pergi ke Belanda. Sejak saat itu, pemerintah kolonial semakin ketat mengawasi perkembangan pemikiran kritis di tanah jajahan. Daftar orang yang harus dibuang pun terus bertambah.

Pemenjaraan juga dialami oleh tokoh-tokoh pergerakan yang dikenal karena tulisan kritis mereka terhadap permerintah kolonial. Beberapa di antaranya adalah Darsono, Marco Kartodikromo, dan Semaoen. Politik perbukuan zaman Belanda secara formal sesungguhnya mulai dibentuk pada 14 September 1908 saat pemerintah mendirikan Commissie voor de Inlandsche School en Volkslectuur (Komisi Bacaan Rakyat) yang dipimpin G. A. J. Hazeu, seorang doktor dalam bidang bahasa dan sastra Nusantara dari Universitas Leiden dan Penasehat Gubernur Jendral untuk urusan bumi putera. Komisi ini bertugas memilih "buku-buku baik yang dapat menjadi bacaan bagi penduduk pribumi" dan memberi pertimbangan kepada Direktur Pendidikan yang mengurus sekolah-sekolah pribumi. Awalnya, tema-tema bacaan yang dipilih komisi ini berkisar pada pelajaran keterampilan teknik, pertanian, tanaman, dan ilmu alam atau yang berkaitan dengan sikap dan perilaku yang baik.

Titimangsa 1917, D.A Rinkes, yang diberi wewenang pemerintah kolonial untuk menata ulang Komisi Bacaan Rakyat, berhasil mengembangkan komisi itu menjadi sebuah lembaga otonom, Kantoor voor de Volkslectuur, yang secara khusus mengatur pengumpulan naskah, pencetakan, penerbitan, dan peredaran buku-buku yang dianggap pemerintah bermutu. Lembaga ini kemudian dikenal sebagai Balai Poestaka. Balai Poestaka tidak hanya berperan menyediakan bacaan-bacaan ringan, tapi juga mendorong minat baca dan membentuk selera rakyat tentang sastra.

Balai Poestaka menerjemahkan dan mengadaptasi karya-karya pengarang Eropa yang terkenal, seperti Charles Dickens dan Mark Twain ke dalam bahasa Melayu, Jawa, Madura, dan Sunda. Selain itu, Balai Poestaka juga menerbitkan hikayat, cerita rakyat, dan kisah perwayangan dari khazanah kesusastraan Jawa, Melayu, dan 
Sunda. Selanjutnya, Balai Poestaka mendorong penulis-penulis pribumi untuk menghasilkan karya-karya mereka sendiri dalam bahasa Melayu Tinggi, seperti Marah Rusli, Sutan Takdir Alisjahbana, dan Armijn Pane. Buku-buku yang diterbitkan Balai Poestaka memiliki kecenderungan yang seragam, yakni tidak berani memuat masalah politik, apalagi kritik terhadap pemerintah kolonial.

Kemajuan Balai Poestaka semakin menguatkan peran pemerintah kolonial memanfaatkan lembaga tersebut untuk menjalankan kontrol yang ketat terhadap barang cetakan sejak pemilihan dan penyuntingan naskah sampai pada penjualan. Di bidang kesusastraan, pengaruh Balai Poestaka masih terasa sampai masa kini. Karya-karya sastra hasil penulis Tionghoa, Eropa peranakan, ataupun pribumi yang sudah beredar jauh sebelum Balai Poestaka berdiri tersingkir dari sejarah kesusastraan Indonesia modern.

Namun, selama masa penjajahan, terdapat periode kritis antara 1920-1926 yang ditandai menjamurnya bacaan liar yang memfasilitasi lahirnya semangat pergerakan. Bacaan liar adalah bagian yang tak terpisahkan dari "mesin pergerakan" untuk mengikat dan menggerakkan kaum kromo-kaum buruh dan kaum petani yang tak bertanah. Bacaan merupakan media penyampaian pesan dari organisasi atau aktivis pergerakan kepada rakyat. Melalui bacaan liar, rakyat mengenal kata-kata baru yang berkaitan dengan gerak perlawanan terhadap kekuasaan kolonial, seperti kapitalisme, sosialisme, internasionalisme, beweging (pergerakan), staking (pemogokan), dan vergadering (rapat umum), dan sebagainya. Bacaan liar melukiskan situasi pergerakan, eksploitasi kolonial, dan mendorong pembacanya untuk berpartisipasi dan bergerak bersama kaum pergerakan untuk menentang kediktatoran kolonial.

Pada masa kolonial, antara 1906-1912, kaum bumi putera baru mempunyai penerbitan sendiri dengan munculnya NV Javasche Boekhandel en Drukkerrij en Handel in Schrijfbehoeften "Medan Priaji" pimpinan R.M. Tirto Adhi Soerjo. Tirto menjadi pelopor pergerakan nasional yang memelopori bacaan fiksi dan nonfiksi untuk mendidik bumi putera. Selain itu, ada percetakan Insulinde yang disokong H.M. Misbach yang menerbitkan Mata Gelap (Mas Marco, 3 jilid, 1914) dan percetakan VSTP (Serikat Buruh Kereta Api dan Tram) yang menerbitkan koran Si Tetap.

Pemerintah kolonial tidak pernah mengeluarkan undang-undang khusus untuk melarang peredaran bacaan liar, tapi mereka berusaha menghambat kelanjutannya dengan menguasai percetakan, penerbitan, dan peredaran bahan bacaan melalui Balai Poestaka. Pemerintah melakukan pelarangan ketika terjadi aksi perlawanan yang dimotori atau 
didukung organisasi-organisasi pergerakan. Misalnya, ketika pada 1920 terjadi pemogokan buruh percetakan van Dorp yang disusul pemogokan buruh percetakan sejumlah surat kabar, yang didukung Sarekat Islam Semarang, pemerintah menyita buku-buku karangan Mas Marco dan menutup toko-toko buku milik organisasi ini.

Runtuhnya bacaan liar erat dengan perkembangan politik nasional, khususnya pemberontakan nasional 1926/1927. Pemberangusan organisasi radikal diikuti dengan pemberangusan produksi bacaan liar sejak pemberontakan itu. Aksi-reaksi berlangsung terus-menerus sepanjang masa penjajahan Belanda. Ketika pemerintahan penjajah berganti di tangan kekuasaan militer Jepang, sensor diganti dengan kontrol total. Hampir semua jenis media digunakan oleh tentara pendudukan Jepang demi kepentingan propaganda.

Implikasinya, semua alternatif pemikiran dan pendapat diseragamkan dengan berbagai cara, tidak jarang dengan kekerasan. Praktik pelarangan buku di Indonesia modern secara resmi muncul pertama kali pada akhir 1950-an, seiring dengan meningkatnya kekuasaan militer dalam politik Indonesia. Pada awal masa kemerdekaan, Indonesia diguncang krisis politik seperti jatuh-bangunnya kabinet, ketegangan antara pimpinan sipil dan militer, serta timbulnya pemberontakanpemberontakan oleh sejumlah perwira militer di Jakarta (Peristiwa 17 Oktober 1952), yang disusul dengan pemberontakan militer lebih besar dan lebih terorganisir di hampir seluruh bagian di Sumatera, Sulawesi, dan Jawa Barat (PRRI/Permesta dan DI/TII). Upaya memadamkan pemberontakan ini memberikan dalih bagi militer, khususnya Angkatan Darat (AD), untuk memperkuat peran mereka dalam menentukan kebijakan politik.

Di tengah situasi itu, pers secara terbuka memberitakan korupsi dan konflik di tubuh militer, kecaman terhadap kebijakan pemerintah, serta konflik politik antarpimpinan parpol. Ironisnya, di tengah penerapan status darurat untuk menghadapi berbagai pemberontakan sejumlah perwira militer yang menamakan gerakan mereka PRRI/Permesta dan DI/TII, KSAD Mayjen AH Nasution selaku Penguasa Militer melalui Peraturan Kepala Staf AD selaku Penguasa Militer mengeluarkan peraturan No. PKM/001/9/1956 yang mengontrol kebebasan berekspresi, terutama pemberitaan pers.

Dengan adanya peraturan tersebut, AD setiap saat dapat melarang peredaran barang-barang cetakan yang dianggap memuat atau mengandung ketajamanketajaman, persangkaan (insinuaties), bahkan penghinaan terhadap pejabat negara, memuat atau mengandung pernjataan permusuhan, kebencian atau penghinaan terhadap golongan-golongan masyarakat, atau menimbulkan "keonaran"'. 
Batasan atas konsep-konsep itu sepenuhnya ditentukan oleh penafsiran subjektif AD. Larangan itu pada awalnya lebih banyak ditujukan kepada pers. Sepanjang 1957, penguasa militer melarang penerbitan tidak kurang dari 33 penerbitan dan menutup 3 kantor berita, termasuk Kantor Berita Antara. Puluhan wartawan diinterogasi, dan belasan di antaranya ditahan di rumah tahanan militer. Setidaknya, 3 buku kumpulan puisi juga dilarang beredar.

Salah satu buku kumpulan puisi adalah karya Sabar Anantaguna yang berjudul Yang Bertanah Air tapi Tak Bertanah, sementara dua lainnya karya Agam Wispi yang berjudul Yang Tak Terbungkamkan dan Matinya Seorang Petani (Lekra, 1961). Brosur Demokrasi Kita, yang dibuat oleh Mohammad Hatta pasca pengunduran dirinya, juga tidak lolos dari pemberangusan. Brosur tersebut adalah tanda dukungan Hatta terhadap Liga Demokrasi yang dibentuk beberapa saat sebelumnya, berisi kritik terhadap pribadi Presiden Soekarno.

Pelarangan brosur itu diikuti penangkapan Hamka, pimpinan Pandji Masyarakat yang pertama kali memuat naskah dalam brosur. Antara Maret 1957 hingga 1 Mei 1963, Penguasa Perang memiliki kekuasaan tak terbatas untuk memberlakukan sensor dan pelarangan terbitan. Nasib dunia penerbitan semakin memburuk karena para penguasa militer di berbagai daerah dengan leluasa dapat mengambil tindakan untuk membungkam pers, terutama yang memberitakan militer tanpa merujuk pada sumber yang berwenang atau pada bagian penerangan militer sendiri. Status keamanan negara diubah dari "keadaan perang" ke "keadaan bahaya" dengan Peraturan Pemerintah Pengganti Undang-Undang No. 23 Tahun 1959 tentang Keadaan Bahaya. Dalam UU tersebut, Penguasa Perang berhak mengontrol berbagai bentuk ekspresi dan menutup percetakan.

Penguasa Perang di antaranya melarang peredaran buku karya Pramoedya Ananta Toer yang berjudul Hoakiau di Indonesia pada 1959 dan memenjarakan penulisnya selama satu tahun (Jones 2013). Adapun rumusan masalah dan tujuan penelitian ini yaitu: mengetahui Bagaimana praktik pelarangan buku oleh Pemerintah Orde Baru dan Apa dampaknya terhadap masyarakat Indonesia saat itu? Dapat memberikan kontribusi pemikiran tentang hasil penelitan sejarah pelarangan buku di masa Rezim Suharto berkuasa.

\section{Tinjauan Pustaka}

\section{Teori Panoptik}

Panoptik (Panopticon) pada awalnya adalah konsep bangunan penjara yang dirancang oleh filsuf Inggris dan teoretisi sosial Jeremy Bentham pada 1785. Konsep desain penjara itu memungkinkan seorang pengawas untuk mengawasi (-opticon) semua (pan-) tahanan, tanpa tahanan itu 
bisa mengetahui apakah mereka sedang diamati. Karena itu, konsep panoptik ini menyampaikan apa yang oleh seorang arsitek disebut "sentimen kemahatahuan yang tak terlihat". Bentham memperoleh ide panoptik ini dari rencana pembangunan sekolah militer di Prancis, yang dirancang untuk memudahkan pengawasan.

Rancangan awal itu berasal dari kakak Bentham, Samuel, yang menjadikan panoptik sebagai solusi bagi rumitnya keterlibatan, dalam upaya menangani sejumlah besar orang. Panoptik oleh Bentham dimaksudkan sebagai model penjara yang lebih murah dibandingkan penjara lain pada masanya, karena hanya membutuhkan sedikit staf (Downing, 2008). Perkembangannya panoptik bukan lagi sekadar desain arsitektur, namun ia menjadi suatu model pengawasan dan pendisiplinan masyarakat, yang juga diterapkan sampai zaman sekarang.

Filsuf sejarawan yang mengulas masalah pendisiplinan masyarakat dengan model panoptik ini adalah Michel Foucault. Desain panoptik ini disebut oleh Michel Foucault dalam bukunya Surveiller et punir: Naissance de la Prison (1975) yang terbit di Prancis, dan lantas diterjemahkan ke bahasa Inggris dengan judul Discipline and Punish: The Birth of the Prison (1977). Desain panoptik ini menjadi metafora bagi masyarakat "disiplin" modern dan kecenderungannya yang menyebar, untuk mengawasi dan menormalisasi (Foucault
1995). Discipline and Punish merupakan penelaahan mekanisme sosial dan teoretikal di belakang perubahan-perubahan masif, yang terjadi pada sistem penghukuman Barat selama zaman modern. Foucault mengawali bukunya dengan mengkontraskan dua bentuk hukuman: kekerasan dan penyiksaan di depan publik yang kacau pada akhir abad ke-18; serta penjadwalan harian yang sangat teratur bagi para tahanan pada awal abad ke-19.

Contoh-contoh ini menunjukkan gambaran, betapa besarnya perubahan dalam sistem penghukuman Barat sesudah kurang dari seabad. Foucault ingin agar para pembaca bukunya mempertimbangkan hal ihwal ini. Bagaimana budaya Barat bisa bergeser begitu radikal? Untuk menjawab hal itu, Foucault mulai menguji penyiksaan itu sendiri. Menurut Foucault, penyiksaan di depan publik merupakan forum teatrikal yang melayani sejumlah maksud yang diniatkan dan tidak diniatkan bagi masyarakat.

Maksud yang diniatkan itu adalah, pertama, pencerminan kekerasan dari kejahatan asal kepada tubuh terpidana untuk dilihat semua orang. Kedua, melakukan pembalasan terhadap tubuh terpidana, di mana upaya oleh yang pihak berkuasa untuk memilikinya, telah dicederai oleh kejahatan. Di sini Foucault berargumen bahwa hukum dianggap sebagai kepanjangan dari tubuh pihak yang berkuasa, dan dengan demikian pembalasan 
terhadap terpidana harus berbentuk menyakiti tubuh terpidana. Pembahasannya terfokus pada dokumen-dokumen bersejarah dari Prancis, tetapi isu-isu yang ditelaahnya tetap relevan bagi setiap masyarakat Barat modern. Karya Foucault ini dianggap sebagai karya yang punya kemungkinan berkembang, dan telah memengaruhi banyak ahli teori dan seniman (Foucault, 1995).

Menurut Foucault, dampak utama panoptik adalah sebegitu rupa sehingga menyebabkan adanya kesadaran dan visibilitas pada tahanan, yang memastikan berfungsinya kekuasaan secara otomatis. Jadi, ia mengatur pelbagai hal yang-pada dampaknya pada si tahanan-pengawasan itu seolah-olah dirasakan bersifat permanen, sekalipun sebenarnya mungkin terjadi ketidaksinambungan pengawasan. Foucault menyatakan, bukan hanya penjara tetapi seluruh struktur hirarkial-seperti tentara, sekolah, rumah sakit dan pabrik telah mengembangkan dalam sejarahnya pembentukan struktur yang mirip panopticon-nya Bentham.

Keterkenalan desain itu saat ini (walaupun tidak memiliki pengaruh yang bertahan lama dalam realitas arsitektural) berasal dari analisis Foucault yang terkenal tentang hal tersebut (Ransom, 2007). Para pengritik sosial kontemporer sering menegaskan bahwa teknologi telah memungkinkan pengerahan strukturstruktur panoptik yang tidak bisa terlihat di seluruh masyarakat. Pengawasan lewat kamera CCTV di tempat-tempat publik adalah contoh teknologi yang membawa cara pandang serius dari orang unggul ke kehidupan sehari-hari populasi. Foucault berpendapat bahwa munculnya penjara sebagai bentuk penghukuman bagi setiap kejahatan tumbuh dari perkembangan disiplin pada abad ke-18 dan ke-19.

Dia melihat ke perkembangan bentuk-bentuk disiplin yang sangat dipercanggih. Yakni, disiplin yang terkait dengan aspek-aspek terkecil dan paling persis dari tubuh manusia. Institusi-institusi modern mensyaratkan bahwa tubuh harus diindividuasikan sesuai dengan tugas-tugas mereka, serta untuk pelatihan, observasi, dan kontrol. Karena itu, disiplin menciptakan keseluruhan bentuk baru individualitas bagi tubuh-tubuh, yang memungkinkan mereka melaksanakan tugasnya dalam bentuk baru organisasiorganisasi ekonomi, politik, dan militer, yang muncul pada zaman modern dan terus berlangsung sampai saat ini.

Individualitas yang mendisiplinkan konstruksi bagi tubuh yang dikontrolnya memiliki empat ciri, yang katakankah membentuk individualitas, yaitu: Selular (menentukan distribusi spasial tubuhtubuh). Organik (memastikan bahwa aktivitas yang dibutuhkan oleh tubuh-tubuh bersifat "alamiah" bagi mereka). Genetik (pengontrolan evolusi selama waktu aktivitas tubuh-tubuh itu), Bersifat 
kombinasi (memungkinkan kombinasi kekuatan dari banyak tubuh ke dalam sebuah kekuatan tunggal yang sangat kuat) (Dillon \& Neal, 2008). Foucault menduga bahwa individualitas ini dapat diterapkan dalam sistem yang secara resmi egalitarian, namun yang menggunakan disiplin untuk mengkonstruksi relasi-relasi kuasa yang non-egalitarian.

Argumen Foucault adalah bahwa disiplin menciptakan "tubuh-tubuh yang tenang dan mudah dikelola" (docile bodies), yang ideal bagi ekonomi, politik, dan perang zaman industri modern-tubuh-tubuh yang berfungsi di pabrik-pabrik, resimenresimen militer yang diperintahkan, dan ruang-ruang kelas di sekolah. Namun, untuk mengkonstruksi tubuh yang tenang dan mudah diatur, lembaga-lembaga pendisiplinan harus sanggup untuk: a) secara terus-menerus mengawasi dan merekam tubuh-tubuh yang dikontrol; b) memastikan internalisasi individualitas pendisiplinan di dalam tubuh yang dikontrol.

Maka, disiplin harus datang tanpa kekuatan yang berlebihan melalui pengawasan yang cermat, dan melebur tubuh-tubuh ke dalam bentuk yang benar melalui observasi. Ini menuntut adanya bentuk partikular dari institusi, yang menurut argumentasi Foucault, dicontohkan oleh panopticon-nya Jeremy Bentham. Panoptik adalah perwujudan puncak dari institusi pendisiplinan modern.
Panoptik memungkinkan observasi terusmenerus yang dicirikan oleh sebuah "tatapan yang tidak setara" (unequal gaze), sebuah kemungkinan observasi yang terusmenerus. Mungkin gambaran yang paling penting dari panoptik adalah bahwa pengaturan itu secara spesifik dirancang sedemikian rupa, sehingga tahanan tidak pernah bisa merasa pasti, apakah ia sedang diawasi atau tidak.

Tatapan yang tidak setara ini menyebabkan internalisasi individualitas pendisiplinan dan kebutuhan tubuh-tubuh yang mudah diatur itu akan adanya teman setahanan. Ini berarti seseorang kecil kemungkinan melanggar peraturan atau hukum jika mereka yakin sedang diawasi, bahkan sekalipun mereka sebenarnya sedang tidak diawasi (Ernst, 2012). Oleh karena itu, penjara, dan khususnya penjara yang mengikuti model panoptik, menyediakan bentuk ideal penghukuman modern. Foucault menganggap, inilah sebabnya mengapa hukuman "lembut" bersifat umum, yang berupa kelompokkelompok kerja untuk publik, kalah oleh penjara.

Perihal ini adalah modernisasi penghukuman yang ideal, karena dominasinya pada akhirnya bersifat alamiah. Di sini Foucault menantang ide yang secara umum diterima, bahwa penjara menjadi bentuk penghukuman yang konsisten berkat keprihatinan kemanusiaan dari kaum reformis, walaupun Foucault 
tidak membantah hal itu. Foucault melakukan hal ini dengan melacak secara cermat pergeseran-pergeseran dalam budaya, yang menjurus ke dominasi penjara, dengan memfokuskan pada tubuh dan pertanyaan-pertanyaan tentang kuasa (Lemm \& Vatter 2015). Penjara adalah bentuk yang digunakan oleh "disiplindisiplin" sebuah kekuatan teknologis baru, yang juga bisa ditemukan (menurut Foucault) pada sekolah, rumah sakit, barak militer, dan lain-lain.

Dalam menguji konstruksi penjara sebagai sarana sentral penghukuman kriminal, Foucault membangun kasus bagi gagasan bahwa penjara menjadi bagian dari sistem yang lebih besar, yang telah menjadi sebuah lembaga berdaulat yang mencakup semuanya. Penjara ialah satu bagian dari jejaring yang sangat besar, yang mencakup sekolah, lembaga militer, rumah sakit, dan pabrik-pabrik, yang membangun sebuah masyarakat panoptik bagi anggotaanggotanya.

Sistem ini menciptakan karir-karir pendisiplinan bagi mereka yang terkurung dalam koridor-koridornya. Sistem ini beroperasi di bawah otoritas ilmiah kedokteran, psikologi, dan kriminologi. Sistem ini juga beroperasi sesuai dengan prinsip-prinsip yang memastikan bahwa ia tidak boleh gagal menghasilkan penjahatpenjahat. Kejahatan itu diproduksi ketika kriminalitas sosial kecil-kecilan tak lagi bisa ditoleransi, dan menciptakan sebuah kelas "pelaku pelanggaran" yang terspesialisasi, yang bertindak sebagai proksi (kepanjangan tangan) polisi dalam mengawasi masyarakat.

Dalam penelitian ini, teori panoptik dari Michel Foucault digunakan sebagai pisau analisa bagi penulis untuk menjelaskan bagaimana lembaga-lembaga pelarangan buku milik para penguasa dijalankan dan bagaimana konstruksi budaya mereka dalam praktik sensor berubah selama berabad-abad di dunia. Berfokus pada praktik sensor buku merupakan cara penting untuk melacak perubahan sepanjang waktu, dan meneroka bagaimana kekuasaan begitu dinamis dalam melakukan pendisiplinan masyarakatnya.

\section{Metode Penelitian}

Metode Penelitian Sejarah menggunakan metode historis, yaitu suatu metode penelitian kualitatif yang khusus digunakan dalam penelitian sejarah dengan melalui tahapan tertentu. Penerapan metode historis ini menempuh tahapantahapan kerja, sebagaimana yang dikemukakan oleh Notosusanto (1971: 17) sebagai berikut:

a. Heuristik, yakni menghimpun jejak-jejak masa lampau

b. Kritik (sejarah), yakni mennyelediki apakah jejak itu sedjati baik bentuk maupun isinja. 
c. Interpretasi, yakni menetapkan makna dan saling berhubungan dari fakta jang diperoleh sedjarah itu.

d. Historiografi, yakni menyampaikan sintesa yang diperoleh dalam bentuk sebuah kisah.

\section{Hasil Dan Pembahasan}

\section{A. Membangun Sistem Kontrol}

Pada masa Orde Baru, kegiatan politik yang bertentangan dengan kebijakan pemerintah dianggap sebagai sebuah kejahatan, sama halnya seperti perampokan atau pencurian yang diatur dalam Kitab Undang-Undang Hukum Pidana. Puluhan orang yang aktif menyuarakan pikiran politiknya menjadi korban dan dijerat dengan 'pasal-pasal penyebar kebencian' (haatzaai artikelen). Pelbagai pasal ini ditetapkan pada zaman kolonial oleh pemerintah Hindia Belanda untuk melindungi penguasa dari perlawanan rakyat pribumi.

Dua pasal di antaranya, yaitu pasal 153 bis dan 161 bis dan ter yang mengerikan, dicabut pada 1946 tatkala pemerintah Republik Indonesia yang masih belia memberlakukan kembali kitab undang-undang hukum pidana Hindia Belanda dengan sedikit perubahan. Dalam sidang-sidang para korban haatzaai artikelen beserta pengacara mereka berulangkali mengkritik penggunaan pasalpasal warisan kolonial, sebagai tindakan yang tidak patut. Amat ironis menurut mereka, bahwa di zaman ini pemerintah Orde Baru justru menerapkan pasal-pasal yang pernah dipakai penguasa kolonial untuk membelenggu kemerdekaan. Para ahli hukum umumnya mendukung pandangan itu, dan mengatakan bahwa pasal-pasal itu sudah kehilangan basis legitimasinya, baik dari segi sosio-historis maupun yuridis; apalagi kalau ditinjau dari perspektif hak asasi manusia internasional.

Seluruh nafas dari instrumen hak asasi manusia internasional berasal dari kritik yang mendasar dan menyeluruh terhadap pengalaman masyarakatmasyarakat yang berada di bawah kekuasaan rezim otoriter. Pasal 19 Kovenan Internasional Hak-Hak Sipil dan Politik yang mengatur masalah kebebasan berbicara, berpikir, dan berpendapat menyebutkan 'keamanan nasional' sebagai batas-batas yang boleh dijaga oleh pemerintahan, tapi sama sekali tidak disinggung masalah 'kewibawaan pemerintah' atau 'kehormatan Presiden'.

Artinya, kritik terhadap pemimpin negara, sekalipun sangat tajam dan mendasar, patut mendapat perlindungan hukum, sejauh tidak bersifat mencemarkan nama baik atau mengganggu haknya sebagai manusia. Pasal-pasal penyebar kebencian itu hanya beberapa dari sekian banyak warisan kolonial di dalam sistem hukum Indonesia era kiwari. Melihat bahwa aturan hukum adalah legal expression dari hubungan kuasa antara negara dan 
masyarakat, maka dapat disimpulkan, bahwa hubungan itu belum mengalami pergeseran yang berarti. Dalam kasus 'pasal-pasal penyebar kebencian', ada pendapat yang keras mengatakan bahwa pergantiannya tidak lebih dari sekadar nama saja, 'Raja/Ratu' diganti 'Presiden' dan 'Kerajaan' diganti 'Republik'. Negara tetap berada pada posisi mendominasi, sementara masyarakat luas dalam posisi didominasi.

Peralatan represif dipakai untuk mempertahankan dominasi ini, dan berkembang semakin canggih seiring terjadinya perlawanan dari masyarakat. Haatzaai artikelen digunakan untuk menghukum kalangan pergerakan yang menentang kekuasaan kolonial, tetapi maksud sebenarnya tidak lain untuk meredam perlawanan secara menyeluruh. Aturan yang sama kemudian dipakai oleh pemerintah Orde Baru umumnya terhadap aktivis mahasiswa dan pemuda. Walaupun dari aspek institusi ada kesejajaran, kepentingan yang dilindungi oleh perangkat-perangkat negara tidak sepenuhnya sama.

Pertanyaannya kepentingan apa yang sesungguhnya dilindungi oleh perangkat represif negara? Pertanyaan itu dengan sendirinya melampui penjelasan legal-formal yang ada di bagian konsideran produk-produk hukum, bahwa peralatan represif dibuat untuk melindungi kepentingan bersama, atau dalam pernyataan lebih abstrak 'menjaga stabilitas nasional'. Juga sudah umum diketahui, bahwa perumusan 'stabilitas nasional' biasanya dilakukan secara sepihak oleh pemegang kuasa, bukan melalui cara-cara yang demokratis seperti pengumpulan pendapat umum. Dalam konteks pelarangan buku, pernyataannya lebih spesifik: kepentingan apa yang sebenarnya dilindungi oleh rezim pelarangan dengan segala perangkat birokrasi dan aturan hukumnya?.

Di masa Orde Baru, gaya Demokrasi Terpimpin yang memberi wewenang besar pada lembaga ekskutif tetap dipertahankan. Partai-partai politik dan dewan perwakilan cenderung menjadi pelengkap sistem politik, dan sejak awal tidak memainkan peran penting dalam pengambilan keputusan. Sebaliknya, pemerintah membantu pembentukan organisasiorganisasi korporatis dan terus mendorong organisasi independen untuk bergabung dalam 'wadah tunggal'.

Di sisi lain, kekuasaan birokrasi negara makin besar, sekaligus, semakin terpusat di tangan badan-badan militer. Jabatan-jabatan sipil yang penting diisi oleh personel militer, terutama yang berkelindan dengan pengawasan dan kontrol, mulai dari tingkat departemen, kantor wilayah, gubernur, sampai bupati. Cara lain ialah membuat lembaga-lembaga baru, seperti rapat, forum atau badan koordinasi, yang memberi ruang bagi intervensi dalam pengambil keputusan. Lembaga liyan yang 
tidak kalah pentingnya adalah Kopkamtib, yang memiliki kekuasaan nyaris tidak terbatas untuk 'memulihkan keamanan dan ketertiban'. Oleh para pengendali negara kemudian dianggap berdiri di atas perbedaan politik dan kepentingan; sebuah senjata ampuh untuk membenarkan tindakan dan menekan para pembangkang (Awaluddin, 2010). Pembentukan lembaga kontrol sedemikian rupa tidak lain untuk menjaga hubungan dominasi di setiap orde.

Dalam khazanah pemikiran politik, pelarangan buku termasuk tindakan represif karena membuntungi hak secara paksa melalui surat keputusan dan aturan tertentu. Dengan begitu, seluruh peralatan dan perlengkapannya dikategorikan sebagai peralatan koersif negara (coercive state apparatus) karena memiliki kekuatan memaksa, dan dibedakan dari peralatan yang bekerja di tingkat ideologi atau kesadaran (ideological apparatus). Peralatan ini bekerja untuk menciptakan konsensus dalam masyarakat bahwa orde atau tatanan yang sedang berjalan adalah yang terbaik, dan untuk itu perlu dijaga keamanan dan ketertibannya.

Dengan lembaga semacam inilah setiap penalaran atau ekspresi yang berbeda dapat dijaga agar tidak berkembang menjadi (dalam rumusan BP7) ancaman, gangguan, hambatan, dan tantangan (AGHT). Sebagian sarjana berpendapat bahwa semua ini dilakukan rezim Orde Baru untuk mempertahankan kepentingan mereka sendiri, sementara yang lainnya berpandangan bahwa birokrasi diciptakan untuk melindungi kepentingan ekonomi dan politik tertentu. Pelarangan buku lebih mungkin disigi sebagai upaya kontrol terhadap masyarakat secara menyeluruh, dan kepentingan yang dilindungi oleh upaya kontrol ini dipakai untuk melindungi kepentingan bersama para pemegang kuasa di segala bidang, yang tidak menginginkan perubahan berarti yang mengancam kedudukan dan dominasi politiknya.

Hal ihwal ini dapat dilihat dalam kasus-kasus pelarangan buku yang dibahas dalam penelitian ini. Dalam studi atau komentar tentang pembatasan kebebasan ekspresi di Indonesia sering muncul simpulan bahwa tidakan pelarangan adalah produk kesewenang-wenangan penguasa yang tidak peduli hukum, atau bahkan menginjak-injak hukum. Dengan kata lain, pemegang kekuasaan yang menjatuhkan larangan telah bertindak menyimpang dari aturan yang berlaku atau membelokkan hukum untuk kepentingan lain di luar keadilan.

\section{B. Mekanisme Pelanggaran}

Pada tahun-tahun pertama Orde Baru, pelarangan buku masih dilakukan serampangan oleh berbagai instansi, tapi umumnya melibatkan pihak militer. Pada periode transisi ini boleh dibilang wewenang pelarangan dan pengawasan praktis terpusat di tangan Kopkamtib, 
sementara lembaga-lembaga kontrol lainnya lebih banyak memberikan bantuan saja. Antara tahun 1968 sampai 1977, Kejaksaan Agung sebagai pemegang kuasa masalah pelarangan tercatat hanya mengeluarkan 10 surat keputusan melarang, berarti rata-rata satu keputusan setiap tahunnya. Sejak 1978 peran Kejaksaan Agung sebagai lembaga pelarangan makin penting, dan tercatat lebih aktif mengeluarkan surat keputusan pelarangan.

Akan tetapi, perihal itu tidak berarti bahwa lembaga-lembaga kontrol lainnya melemah dalam urusan pelarangan. Untuk melihat hubungan antarlembaga yang secara keseluruhan membentuk rezim pelarangan, ada baiknya melihat prosedur pelarangan buku dalam praktik, artinya tidak hanya seperti ditetapkan oleh undangundang.

Dengan pengamatan ini juga terlihat ruang-ruang intervensi bagi lembaga lain yang masih terus terjadi. Dari uraian pasalpasal dan penjelasan UU No. 4/Pnps/1963 terlihat prosedur pelarangan buku oleh Kejaksaan Agung terbagi dalam empat tahap: pengumpulan bahan, penyelidikan/penelitian, pengambilan keputusan, dan penyitaan (JKB 1999). Pasal 2 undang-undang tersebut mewajibkan setiap percetakan untuk mengirimkan hasil cetakannya kepada Kepala Kejaksaan Negeri setempat, selambat-lambatnya 48 jam pasca cetak. Untuk barang cetakan yang diproduksi di luar negeri tetapi diterbitkan di Indonesia, maka kewajiban itu jatuh ke pundak penerbitnya. Pelanggaran terhadap ketentuan ini dikenakan hukuman denda $\mathrm{Rp}$ 10.000,00. Di samping itu Jaksa Agung juga berwenang, seperti diatur dalam pasal 4, untuk memeriksa semua barang cetakan yang dikirim dari luar negeri, termasuk yang dikirim melalui pos. Menurut pengakuan Kejaksaan Agung, ketentuan pasal 2 sering diabaikan oleh percetakan dan penerbit, sehingga seringkali harus turun ke lapangan mencari buku-buku untuk diperiksa.

Untuk keperluan itu, Jaksa Agung menugaskan Jaksa Agung Muda Bidang Intelijen beserta stafnya untuk mengumpulkan barang cetakan yang diduga berbahaya secara rutin. Pada November 1993 misalnya, Kejaksaan Tinggi Jawa Tengah memeriksa kiriman ribuan buku untuk Universitas Diponegoro dari 10 mahasiswa Indonesia yang belajar di Amerika Serikat. Dalam kiriman itu, 87 judul dicurigai mengandung ajaran komunis, yang kemudian disita untuk diperiksa lebih lanjut.

Bagaimanapun, inisiatif pemeriksaan sebuah buku selalu datang dari pihak kejaksaan. Lembaga-lembaga pemerintah dan organisasi masyarakat kerap kali mengadukan beredarnya barang cetakan yang meresahkan kepada Kejaksaan Agung, seperti terlihat dari beberapa contoh di bawah ini: 
1. September 1968. Pengurus Besar Front Muballigh Islam di Medan mengirim surat kepada Kejaksaan Agung menuntut pelarangan ensiklopedi Funk and Wagnalls. Alasannya karena ensiklopedi itu memuat gambar Nabi Muhammad saw yang tidak diperkenankan dalam Islam, dan memberikan informasi yang keliru mengenai agama Islam. Jaksa Agung meluluskan tuntutan itu melalui SK No. Kep-121/DA/11/1968.

2. Juni 1982. Kantor Departemen Agama Tegal dan Brebes mengirim surat kepada Kanwil Departemen Agama Jawa Tengah. Pejabat kantor itu mempersoalkan peredaran buku Kunci Mencari Rizqi karya KH. Zahwan Anwar, yang dianggap 'bisa menimbulkan dampak negatif bagi akidah Islam'. Kanwil Departemen Agama Jawa Tengah mendukung pernyataan itu dan menarik buku itu tanoa menunggu keputusan Jaksa Agung.

3. Juni 1986. Dalam dengar pendapat Komisi I DPR dengan Bakin, Wakil Ketua Komisi I dari F-KP Rusli Desa, mendesak pemerintah melarang buku Militer dan Politik karya Harold Crouch yang diterbitkan oleh Sinar Harapan beberapa bulan sebelumnya. Menurutnya, buku itu akan 'menyebabkan ketidakpercayaan rakyat terhadap Presiden'. Buku itu dilarang sebulan kemudian melalui SK No. Kep-044/JA/6/1986.

4. September 1995. Forum Studi dan Komunikasi (Fosko) '66 mendatangi
Kejaksaan Agung menyampaikan gugatan terhadap buku Memoar Oei Tjoe Tat yang disunting oleh Pramoedya Ananta Toer dan Stanley Adi Prasetyo. Dalam gugatan itu dikatakan, 'kalau ditemukan hal yang dapat membahayakan kepentingan persatuan dan kesatuan bangsa, buku itu harus dilarang.' Tanggal 25 September, dua minggu pasca kunjungan delegasi itu, Jaksa Agung melarang buku tersebut melalui SK No, Kep-111/JA/9/95.

Usulan pelarangan secara rutin dilakukan oleh lembaga pemerintah lain, melalui berbagai forum atau rapat koordinasi. Salah satu yang penting adalah rapat koordinasi bidang politik dan keamanan yang dipimpin oleh Menko Polkam. Rapat itu berlangsung rutin dan dihadiri oleh Jaksa Agung serta pejabat pemerintah dan petinggi militer, seperti Panglima ABRI.

Dari konsideran surat-surat keputusan pelarangan terlihat bahwa beberapa lembaga, antara lain: Bakin, Bakorstanas, Bais ABRI, Polri, Departemen Agama, secara rutin mengirim pandangannya langsung kepada Jaksa Agung melalui surat. Hubungan yang lebih langsung (meskipun mungkin berlangsung secara informal) dapat ditelusuri dari posisi Jaksa Agung Muda Bidang Intelijen, yang salah satu tugasnya ialah mengumpulkan informasi tentang buku-buku rawan. Posisi ini hampir selalu ditempati oleh perwira 
tinggi militer, yang lama bekerja dalam bidang intelijen. Dalam pasal 12 Keppres 55/1991 tentang susunan organisasi dan tata kerja Kejaksaan Agung disebutkan:

Jaksa Agung Muda Intelijen
mempunyai tugas dan wewenang
melakukan kegiatan intelijen
yudisial di bidang ideologi, politik,
ekonomi, keuangan, sosial budaya,
dan pertahanan keamanan untuk
mendukung kebijakan penegakan
hukum dan keadilan baik preventif
maupun represif, melaksanakan dan
atau turut menyelenggarakan
ketertiban dan ketentraman umum
serta pengamanan pembangunan
nasional dan hasil-hasilnya
berdasarkan peraturan perundang-
an-undangan dan kebijaksanaan
yang ditetapkan oleh Jaksa Agung.

Dengan fungsi resmi seperti ini, praktis Jaksa Agung Muda Intelijen dapat berhubungan dengan semua instansi penyelenggara ketertiban dan ketenteraman umum. Di samping ruangruang yang memberi peluang intervensi, ada dua lembaga yang secara langsung menghubungkan kejaksaan dengan aparat keamanan dan birokrasi sipil. Lembaga pertama adalah Musyawarah Pimpinan Daerah yang dibentuk melalui Keppres 10/1986.

Dalam keputusan itu disebutkan tugas Muspida antara lain ialah koordinasi seluruh aparatur negara di tingkat daerah untuk mencegah dan menanggulangi gangguan ketenteraman dan ketertiban di dalam masyarakat. Di tingkat provinsi, lembaga ini melibatkan Jaksa Tinggi,
Gubernur, Panglima Daerah Militer (Pangdam), dan Kepala Kepolisian Daerah (Kapolda), sementara di tingkat kabupaten, terdiri atas Kepala Kejaksaan Negeri, Bupati atau Wali Kota, Komandan Distrik Militer (Dandim), dan Kepala Kepolisian Resort (Kapolres). Gangguan keamanan seperti peredaran buku-buku berbahaya sering dibicarakan dalam lembaga ini, yang selanjutnya juga menjadi bahan pertimbangan Kejaksaan setempat untuk mengambil tindakan, terkadang mendahului keputusan Jaksa Agung.

Lembaga lain yang tidak kurang pengaruhnya adalah Bakorstanas yang dibentuk dengan Keppres 29/1988 sebagai ganti Kopkamtib yang dibubarkan beberapa waktu sebelumnya. Secara umum, lembaga ini sama fungsi dan tugasnya seperti Muspida, tetapi tekanan lebih besar pada aspek keamanan. Di tingkat nasional, lembaga ini dipimpin oleh Panglima ABRI yang bertanggung jawab langsung ke Presiden dan wakil-wakil dari Mabes ABRI, kelima angkatan, Kepolisian, Kejaksaan Agung, dan BAKIN sebagai anggota tetap.

Pimpinan juga dapat meminta setiap departemen atau instansi pemerintah untuk mengirimkan wakilnya sebagai anggota tidak tetap jika diperlukan. Dari segi keanggotaan, Bakorstanas berbeda dari Kopkamtib dengan melibatkan unsur lain di luar militer. Akan tetapi, struktur dan kontrol kelembagaannya praktis tidak berubah, karena baik di tingkat nasional 
maupun regional, kepemimpinannya ada di tangan pejabat militer setempat dan keuangannya dibebankan kepada Mabes ABRI. Dari gambaran ini terlihat bahwa pola yang berlaku pada awal kekuasaan Orde Baru, di mana militer sangat berperan dalam kontrol terhadap arus informasi terus bertahan, sekalipun nampak tumpangtindih dan pembagian tugasnya menjadi tidak jelas.

Kejaksaan Agung tentunya lebih berperan aktif, tapi sesungguhnya tidak lepas dari pengaruh bahkan campur tangan dari pihak militer. Lembaga-lembaga itu juga berperan dalam tahap selanjutnya, yaitu proses penelitian/penyelidikan atas sebuah buku. Pada masa awal Orde Baru 'kerjasama' ini tidak dilembagakan dan diumumkan kepada masyarakat luas. Baru pada Oktober 1989, keluar keputusan membentuk clearing house yang berfungsi meneliti isi sebuah buku dan memberi rekomendasi langsung kepada Jaksa Agung, sebelum mengambil keputusan.

Namun dari kasus-kasus yang ada, seringkali sebuah buku dilarang hanya selang beberapa minggu dari waktu penerbitannya, sehingga dapat diperkirakan bahwa Jaksa Agung sepenuhnya mempercayai rekomendasi dari clearing house atau pihak-pihak lain, tanpa melakukan konfirmasi melalui penelitian sendiri. Pelembagaan hubungan instansiinstansi kontrol pikiran ini, tidak berarti intervensi langsung sudah selesai. Dalam kasus pelarangan Nyanyi Sunyi Seorang Bisu karya Pramoedya Ananta Toer pada Maret 1995, Jaksa Agung mencantumkan surat dari Badan Intelijen ABRI sebagai salah satu bahan pertimbangannya. Tahap selanjutnya, adalah keputusan pelarangan. Setelah mendengarkan masukan dari clearing house dan instansi-instansi lain, Jaksa Agung menjatuhkan larangan melalaui surat keputusan.

Dalam surat ini, Jaksa Agung selalu merujuk pada UU No. 15/1961 tentang Kejaksaan Agung (kemudian diganti dengan UU No. 5/1991) serta UU No. 4/Pnps/1963 sebagai landasan hukumnya. Pada bagian keputusan disebutkan bahwa pelarangan itu berlaku di seluruh wilayah hukum Republik Indonesia, serta pihak yang menyimpan, memiliki, dan memperdagangkan barang cetakan itu harus menyerahkannya kepada Kepala Kejaksaan Negeri atau Kepala Kejaksaan Tinggi setempat. Surat-surat keputusan itu biasanya hanya mencantumkan alasan yang umum, seperti merendahkan martabat Kepala Negara RI, mengadu domba golongan, dan tentunya mengganggu ketertiban umum.

Hanya dalam beberapa kasus, Jaksa Agung memberikan alasan yang cukup lengkap dan menunjuk bagian-bagian yang dianggap 'mengganggu ketertiban umum', serta penjelasan lebih lanjut melalui siaran pers. Keputusan Jaksa Agung ini kemudian diumumkan kepada masyarakat melalui surat kabar atau media massa lainnya. 
Penulis dan penerbit hampir tidak pernah diberitahu secara langsung bahwa barang cetakan mereka sudah dinyatakan dilarang, dan dari sejumlah wawancara diketahui bahwa mereka umumnya mendapat informasi dari media massa. Kadang-kadang pengumuman ini dilakukan terlambat, bahkan sampai dua bulan setelah surat keputusan dikeluarkan.

Pada tahap pelarangan ini juga sering terjadi tumpang-tindih tindakan antara Jaksa Agung dengan Kejaksaan Tinggi, Kejaksaan Negeri, maupun lembagalembaga lain. Selama bulan Mei dan Juni 1995, Kejaksaan Tinggi Jawa Barat menarik buku terjemahan Desain Yahudi atau Kehendak Tuhan, karena dianggap bisa meresahkan umat muslim. Menghindari perdebatan perihal tumpang-tindihnya wewenang ini, Kajati Jawa Barat H. Soegeng Marsigit, SH mengatakan tindakannya berbeda dengan penyitaan, walaupun akibat yang ditimbulkannya sama.

Di atas sudah disebutkan bahwa Kanwil Departemen Agama Jawa Tengah juga pernah melakukan tindakan serupa terhadap buku Kunci Mencari Rizqi. Departemen Pendidikan dan Kebudayaan juga melakukan hal ihwal yang sama, meskipun biasanya berlaku terbatas di wilayah kerjanya saja. Menghadapi ini, Jaksa Agung beberapa kali menguatkan tindakan itu dengan menjatuhkan pelarangan melalui surat keputusan. Surat keputusan Jaksa Agung biasanya diikuti oleh instruksi kepada kepala-kepala Kejaksaan Tinggi dan Kejaksaan Negeri di seluruh Indonesia untuk mengambil tindakan pengamanan terhadap buku yang dilarang. Aparat kejaksaan dan kepolisian lantas mendatangi alamat penerbit dan percetakan, jika tercantum, dan menyita semua barang cetakan terlarang yang masih tersisa. Pasca dibersihkan, sasaran berikutnya adalah agen atau toko buku yang diketahui menjual barang cetakan tersebut.

Dalam instruksi itu tidak disebutkan ketentuan ganti rugi, baik bagi penerbit maupun toko buku, sehingga sering keduanya mengalami kerugian besar karena tindakan itu. Di samping itu, Jaksa Agung juga memberi instruksi melakukan Operasi Yustisi untuk menyita buku terlarang dari tangan masyarakat dengan penggeledahan rumah atau di jalan-jalan. Dalam pasal 1 ayat (3) UU No. 4/Pnps/1963 disebutkan ancaman hukuman satu tahun bagi siapa saja yang melanggar keputusan Jaksa Agung. Sampai saat ini belum pernah diketahui kasus hukum yang memperkarakan seseorang karena menyimpan barang cetakan terlarang.

Akan tetapi, hukuman yang jauh lebih berat pernah dialami oleh Bonar Tigor Naipospos, Bambang Isti Nugroho, dan Bambang Subono dari Yogyakarta karena menjual buku-buku karangan Pramoedya Ananta Toer. Jaksa Penuntut Umum ketiganya tidak menggunakan pasal-pasal UU No. 4/Pnps/1963, tapi justru UU No. 
11/Pnps/1963 tentang pemberantasan kegiatan subversif. Pasca melalui proses pengadilan yang kontroversial, ketiganya dihukum penjara selama enam sampai delapan setengah tahun. Titimangsa 1993, beberapa mahasiswa Timor Timur ditahan oleh polisi di daerah asalnya karena membawa buku-buku yang diterbitkan organisasi non-pemerintah di Jakarta.

Sekalipun buku-buku tersebut tidak masuk daftar larangan, sehingga boleh diedarkan dengan bebas, mereka sempat ditahan dan diinterogasi oleh kepolisian setempat. Nasib serupa menimpa Rachmad Buchori alias Buyung RB, sekretaris pribadi Soebadio Sastrosatomo, pengarang brosur Era Baru Pemimpin Baru yang dilarang melalui SK No. Kep-020/JA/3/1997 tanggal 4 Maret 1997 karena dituduh mengedarkan 'selebaran gelap'. Dalam surat penahanannya juga tidak tercantum pelanggaran terhadap UU No. 4/Pnps/1963, sehingga para pengacaranya mempertanyakan keabsahan penahanan tersebut.

Buku-buku yang berhasil disita oleh aparat kejaksaan atau aparat keamanan lainnya, kemudian dikirimkan kepada kantor kejaksaan tinggi setempat untuk dimusnahkan, dengan cara membakar. Cara ini selanjutnya mengundang protes karena mengingatkan orang kepada tindakan Jepang atau Jerman di masa Perang Dunia II, dan pembakaran massal buku-buku USIS pada 1960-an. Mulai akhir 1980-an, ada ketentuan baru untuk memusnahkan buku dengan cara daur ulang menjadi bubur kertas. Untuk buku-buku yang dinilai kontroversial, Kejaksaan Agung juga mengambil sikap yang kontroversial dengan membakar sendiri buku-buku itu dengan diliput oleh media massa (cetak maupun elektronik). UU No. 4/Pnps/1963 sendiri tidak memberi keterangan tentang pemusnahan barang cetakan, sehingga bisa dikatakan bahwa pembakaran maupun daur ulang adalah keputusan Jaksa Agung sendiri.

Penjelasan pasal 1 UU itu sebenarnya mengatakan bahwa pelarangan dilakukan mengingat kesadaran hukum rakyat pada suatu ketika. Artinya, barang cetakan tidak selamanya dianggap terlarang, karena konsep 'ketertiban umum' juga berubah mengikuti perkembangan sosialpolitik. Pemusnahan buku dengan begitu juga perlu dipertanyakan karena menutup kemungkinan meninjau kembali pelarangan berdasarkan perkembangan kesadaran hukum rakyat.

Satu aspek penting dari pembahasan tentang hukum dan lembaga ini adalah kriteria yang dikembangkan oleh Kejaksaan Agung selama ini dalam pelarangan buku. Di atas sudah disinggung beberapa batas, seperti Marxisme-Leninisme/Komunisme, barang cetakan dengan aksara Cina dan semua tulisan dari pengarang yan 'diduga terlibat G30S/PKI'. Di bawah Orde Baru, Penpes No. 4/1963 mengalami perubahan dengan digantinya beberapa kata kunci seperti Revolusi dan Sosialisme karena 
dianggap tidak sesuai lagi dengan haluan baru yang ditetapkan. Rumusan ketertiban umum dengan begitu sepenuhnya menjadi wewenang Jaksa Agung seperti diatur dalam penjelasan pasal $1 \mathrm{UU}$ itu. Dalam pelarangan buku selama ini, Jaksa Agung juga cenderung memberi tafsiran sendiri, tanpa merasa perlu merujuk kepada ketentuan hukum lain. Hanya ada beberapa undangundang yang dirujuk untuk memperkuat argumentasinya, seperti UU No. 1/Pnps/1965 tentang pencegahan dan penyalahgunaan agama.

Titimangsa 1989, majalah JakartaJakarta, berdasarkan informasi dari Kejaksaan Agung menerbitkan daftar kriteria yang mendedahkan isi 'mengganggu ketertiban umum'. Disebutkan antara lain:

1. Bertentangan dengan Pancasila dan UUD 1945.

2. Mengandung dan menyebarkan ajaran atau paham MarxismeLeninisme/Komunisme.

3. Merusak persatuan dan kesatuan masyarakat, bangsa, dan negara RI.

4. Merusak kepercayaan masyarakat terhadap kepemimpinan nasional.

5. Merusak kepercayaan masyarakat terhadap kepemimpinan nasional.

6. Merusak akhlak dan memajukan pencabulan/pornografi.

7. Memberikan kesan anti-Tuhan, anti agama dan penghinaan terhadap salah satu agama yang diakui di Indonesia, sehingga merupakan penodaan dan merusak kerukunan hidup beragama.

8. Menimbulkan pertentangan SARA.

9. Bertentangan dengan GBHN, dan lainlain (Fauzan, 2003).

Sifat karet dari konsep ketertiban umum terus-menerus menjadi pertanyaan ahli-ahli hukum dan aktivis hak asasi manusia, karena membuka kemungkinan tindakan sewenang-wenang Kejaksaan Agung maupun aparat lain yang memberi masukan. Di atas sudah diperlihatkan bagaimana rezim pelarangan ini melakukan konsolidasi terus-menerus dengan menyatukan langkah lembaga-lembaga kontrol, mengembangkan kriteria yang lebih ketat, dan pelbagai tindakan lainnya.

Semua ini terjadi dalam situasi sejarah tertentu, dan karena itu konsep 'ketertiban umum' dibentuk oleh pengalaman pemegang kuasa peralatan represif menghadapi perlawanan atau apa saja yang dianggap 'ancaman'. Menyebarkan ajaran Marxisme-Leninisme/Komunisme misalnya, dianggap kejahatan karena pengalaman pemegang kuasa Orde Baru berhadapan dengan Partai Komunis Indonesia (PKI).

Baru pada tahap selanjutnya pengalaman nyata ini menjadi umpan bagi fantasi yang menciptakan ukuran-ukuran baru selesai dengan perkembangan zaman. Konsep 'ketertiban umum' yang begitu abstrak dan bersifat karena juga dikritik karena menciptakan kebingungan di dalam 
masyarakat. Satu-satunya pegangan untuk memahami apa yang boleh dilakukan dan apa yang tidak adalah keputusan dari pemegang kuasa sendiri, betapapun pemegang kuasa itu selalu merujuk pada undang-undang atau aturan yang berlaku.

Dalam pelarangan buku, perkembangannya sama saja. Tindakan pelarangan yang sulit dimengerti ini akhirnya hanya menciptakan ketakutan bagi masyarakat, khususnya penulis dan penerbit. Sebagian berkembang lebih jauh ke sikap sinis dan apatis yang berakibat pembunuhan kreativitasnya sendiri. Tidak adanya konsistensi dan kejelasan kriteria mungkin menjadi sebab utama di sini.

\section{Penutup}

Peristiwa 1965 yang terjadi pada periode ini menjadi titik balik bagi Indonesia. Dimulai dari peristiwa G30S, yang kemudian berlanjut pada penumpasan dan penghancuran lembaga-lembaga yang dianggap berafiliasi pada PKI serta anggotaanggotanya. Lembaga terpenting yang dibentuk pada periode ini adalah Komando Pemulihan Keamanan dan ketertiban (Kopkamtib) (tepatnya dibentuk pada 10 Oktober 1965).

Lembaga ini memiliki wewenang besar untuk mengambil tindakan apa saja dalam rangka 'memulihkan keamanan dan ketertiban'. Hasilnya: jutaan orang diperkirakan mengalami kekerasan, dibunuh dan ditangkap tanpa proses peradilan karena didakwa sebagai anggota atau simpatisan PKI dan ormas-ormas yang berafiliasi dengannya. Secara perlahan, kekuatan kiri dimusnahkan dari Indonesia, tidak hanya dengan cara menumpas organisasi-organisasinya, tapi juga dengan menciptakan sikap anti terhadap ideologinya.

Selain membentuk lembaga pengawasan keamanan dan ketertiban ini, pemerintah juga menetapkan Tap MPR XXV/ MPRS/ 1966 yang membubarkan PKI dan melarang ajaran-ajaran MarxismeLeninisme/ Komunisme. Ketetapan ini menjadi alat penting untuk mengontrol masyarakat secara luas dan menjadi dasar penyusunan berbagai peraturan yang mengekang kebebasan berekspresi dan berkumpul yang tidak terbatas pada bekas anggota PKI atau pengikut MarxismeLeninisme/Komunisme. Sama seperti pada masa Orde Lama, Kejaksaan Agung sebenarnya hanya menerima pengaduan dari lembaga-lembaga lain dan menerbitkan SK pelarangan berdasarkan pengaduan tersebut.

Dari konsideran surat-surat keputusan pelarangan memang terlihat bahwa lembaga-lembaga lain seperti BAKIN, Bakorstanas, Bais, ABRI, Polri, Departemen Agama, secara rutin mengirim pandangannya langsung kepada Jaksa Agung. Dalam praktiknya, memang posisi Jaksa Agung Muda bidang Intelijen (JAM Intel) yang hampir selalu ditempati oleh 
perwira tinggi militer, dengan mudah berhubungan dengan semua instansi penyelenggara ketertiban dan ketentraman umum dalam mengumpulkan informasi tentang buku-buku rawan. Kerja sama informal antara jaksa agung dengan lembaga-lembaga (militer) lainnya baru diformalkan pada Oktober 1989 ketika Kejaksaan Agung membentuk Clearing House yang berfungsi meneliti isi sebuah buku dan memberi rekomendasi langsung kepada Jaksa Agung.

Melalui SK No. Kep-114/ JA/ 10/ 1989, clearing house secara resmi bekerja di bawah Jaksa Agung dan terdiri atas 19 anggota dari JAM Intel dan Subdirektorat bidang pengawasan media massa, Bakorstanas, Bakin, Bais, ABRI (kemudian menjadi BIA), Departemen Penerangan, Departemen Pendidikan dan Kebudayaan, serta Departemen Agama.

Lembaga pemerintah lain, selain kejaksaan agung yang melarang buku adalah Departemen Pendidikan dan Kebudayaan melalui Instruksi Menteri Pendidikan Dasar dan Kebudayaan RI no. 1381/1965 tentang Larangan Mempergunakan Buku-buku Pelajaran, Perpustakaan dan Kebudayaan yang Dikarang oleh Oknum-oknum dan Anggotaanggota Ormas/Orpol yang Dibekukan Sementara Waktu Kegiatannya, disertai dengan dua buah lampiran. Lampiran pertama berisi 11 daftar buku pelajaran yang dilarang pemakaiannya, antara lain buku-buku karangan Soepardo SH, Pramoedya Ananta Toer, Utuy T. Sontani, Rivai apin, Rukiyah, dan Panitia Penyusun Lagu Sekolah Jawatan Kebudayaan. Sedangkan lampiran kedua berisi 52 bukubuku karangan pengarang-pengarang LEKRA yang harus dibekukan seperti Sobron Aidit, Jubar Ayub, Klara Akustian/A.S Dharta, Hr. Bandaharo, Hadi, Hadi Sumodanukusumo, Riyono Pratikto, F.L Risakota, Rukiah, Rumambi, Bakri Siregar, Sugiati Siswadi, Sobsi, Utuy Tatang. S, Pramoedya Ananta Toer, Agam Wispi, dan Zubir A.A.

Selain Departemen P\&K, Menteri Perdagangan dan Koperasi juga mengeluarkan Keputusan Menteri no. 286/ KP/ XII/ 78 yang diturunkan dalam Keputusan Direktur Jenderal Perdagangan Luar Negeri No. 01/ DAGLU/ KP/ III/ 79 melarang impor, perdagangan dan pengedaran segala jenis barang cetakan dalam huruf/ aksara dan bahasa Cina. Pada masa itu, pemerintah Cina yang berideologi komunisme, dianggap berbahaya dan mengimpor barang cetakannya dapat membuka kesempatan untuk menyebarluaskan ideologi tersebut.

Larangan ini membuat pengecualian untuk barang cetakan yang bersifat ilmiah, namun barang-barang tersebut harus memperoleh persetujuan dari Departemen P\&K, ijin beredar dari Kejaksaan Agung dan importir pelaksana harus memiliki TAPPI(S) serta ditunjuk oleh Departemen 
Perdagangan dan Koperasi setelah mendengar pendapat Kejaksaan Agung. Dalam praktiknya, selain menyita buku, pemerintah Orde Baru juga menyita dan memusnahkan kaset dan CD berirama mandarin serta beraksara Cina.

Tindakan pelarangan ini selain berkaitan dengan pemutusan hubungan dengan Cina, juga terkait dengan politik diskriminasi warga Tionghoa di dalam negeri. Arkian, Pelarangan buku masih dapat terus terjadi di masa mendatang selama UU No. 4/PNPS/1963 terus dipertahankan.

\section{Daftar Pustaka}

Baez, Fernando. 2017. Penghancuran Buku dari masa ke masa. Edisi Baru. Serpong, Tangerang Selatan: Marjin Kiri.

Dillon, Michael dan Andrew W. Neal (eds.). 2008. Foucault on Politics, Security, and War. London: Palgrave.

Downing, Lisa. 2008. The Cambridge Intoduction to Michel Foucault. Cambridge: Cambridge University.

Ernst, Anne Brunon. 2012. Utilitarian Biopolitics: Bentham, Foucault, and Modern Power. London: Pickering \& Chatto.

Fauzan. 2003. Mengubur Peradaban: Politik Pelarangan Buku di Indonesia. Yogyakarta: LKIS dan YSIK.

Fischer, Steven Roger. 2003. A History of Reading. London: Reaktion Books.

Foucault, Michel. 1995. Discipline and Punish: The Birth of the Prison. New York: Vintage Books.

Jaringan Kerja Budaya. 1999. Menentang Peradaban: Pelarangan Buku di Indonesia. Jakarta: ELSAM.
Jones, Tod. 2013. Culture, Power, and Authoritarianism in the Indonesian State: Cultural Policy across the Twentieth Century to the Reform Era. Leiden \& Boston: Brill.

Ladenson, Elisabeth. 2013. "Censorship", in Michael F. Suarez \& H. R. Woudhuysen (eds.). The Book: A Global History. halaman. 169-182. Oxford: Oxford University.

Lemm, Vanessa dan Miguel Vatter (eds.), 2015. The Government of Life: Foucault, Biopolitics, and Neoliberalism. USA: Fordham University Press.

Maguel, Alberto Manguel. 1998. A History of Reading. London: Flamingo.

Ransom, John S. 2007. Foucault's Disipline: The Politics of Subjectivity. London: Duke University Press.

Ricklefs, M.C., 2001, A History of Modern Indonesia since c. 1200. Third Edition. London: Palgrave.

Yusuf, Iwan Awaluddin. 2010. Pelarangan Buku di Indonesia: Sebuah Paradoks Demokrasi dan Kebebasan Berekspresi. Jakarta: Fredrich Ebert Stifyung \& Pr2media. 